\title{
HAS JOB SECURITY VANISHED IN LARGE CORPORATIONS?
}

\author{
Steven G. Allen \\ Robert L. Clark \\ Sylvester J. Schieber
}

Working Paper 6966

http://www.nber.org/papers/w6966

\author{
NATIONAL BUREAU OF ECONOMIC RESEARCH \\ 1050 Massachusetts Avenue \\ Cambridge, MA 02138 \\ February 1999
}

Tomeka Hill, Research Associate, Watson Wyatt provided excellent research assistance in the development of this paper. This paper was presented at the Russell Sage Foundation conference "Changes in Job Stability and Job Security" and at seminars at NC State University and the National Bureau of Economic Research. Any views expressed in this paper are those of the author only and not those of the National Bureau of Economic Research.

- 1999 by Steven G. Allen, Robert L. Clark, and Sylvester J. Schieber. All rights reserved. Short sections of text, not to exceed two paragraphs, may be quoted without explicit permission provided that full credit, including ${ }^{\circ}$ notice, is given to the source. 
Has Job Security Vanished in Large Corporations?

Steven G. Allen, Robert L. Clark, and Sylvester J. Schieber

NBER Working Paper No. 6966

February 1999

JEL No. J6, L2

\begin{abstract}
The prevailing wisdom in media accounts is that job stability has vanished, especially for those in large corporations. Academic studies of job stability have found little difference between the 1990s and earlier decades, but these studies have not been able to focus on large firms. This paper provides the first detailed analysis of job stability in large corporations in the 1990s using a sample of 51 firms that are clients of Watson Wyatt Worldwide. We find that mean tenure and the percentage of employees with 10 or more years of service have actually increased in our sample. Even in large firms with shrinking employment, the odds that a worker would be with the same employer five years later were higher than the same odds for the labor market as a whole. There is no evidence that mid-career employees have been singled out in downsizing decisions; their turnover rate is the same in both growing and downsizing firms. Regression analysis shows that the impact of downsizing is still being borne by the most junior workers and that there is no evidence that rising wage differentials by experience are encouraging firms to substitute junior for senior workers.
\end{abstract}

Steven G. Allen

College of Management

NC State University

Raleigh, NC 27695-7229

and NBER

steve_allen@ncsu.edu

Robert L. Clark

College of Management

NC State University

Raleigh, NC 27695-7229

robert_clark@ncsu.edu

Sylvester J. Schieber

Watson Wyatt Worldwide

6707 Democracy Boulevard Suite 800

Bethesda, MD 20817-1129

Syl_Schieber@watsonwyatt.com 
"Forget any idea of career-long employment with a big company."

Time, November 22, 1993, p. 37

\section{Introduction}

During the past decade, the U.S. labor market has undergone considerable change, especially as increased international competition and continued technological innovation have created pressures for firms to reduce labor costs substantially. In reporting on these events, it is rare for a week to go by without headlines about plant closings, layoffs, or restructurings. The prevailing wisdom in media accounts is that many workers who had been sheltered from layoffs in earlier decades are no longer protected. Particular attention has been paid to layoffs of white collar workers, workers employed in large corporations, and workers in the middle of their careers. ${ }^{1}$ Media accounts focus on the plight of middle-aged and older workers, who now account for a larger share of job losers than they did in the past. ${ }^{2}$

This perception also shows up in surveys of public opinion. Church (1993) reports that in a Time-CNN poll in 1993, two-thirds thought that job security was worse than it was two years ago (when the unemployment rate was the same) and 53 percent thought that this problem will last for many years. In a poll conducted as part of the weeklong New York Times (1996) series, 46 percent of the respondents said they were worried about becoming unemployed and 72 percent

\footnotetext{
${ }^{1}$ The following quote from the weeklong series "The Downsizing of America" in the New York Times (1996) captures much of today's prevailing wisdom (italics added for emphasis): "More than 43 million jobs have been erased in the United States since 1979 ... Many of the losses come from the normal churning as stores fail and factories move. And far more jobs have been created than lost over that period. But increasingly the jobs that are disappearing are those of higher-paid, white-collar workers, many at large corporations, women as well as men, many at the peak of their careers. Like a clicking odometer on a speeding car, the number twirls higher nearly each day. ... What distinguishes this age are three phenomena: white-collar workers are big victims; large corporations now account for many of the layoffs, and a large percentage of the jobs are lost to "outsourcing" -- contracting out work to another company, usually within the United States."

${ }^{2}$ The widely-cited New York Times (1996) report has a graphic showing the share of laid off workers under age 30 had fallen from 40 to 25 percent between 1981-83 and 1991-93. The share of laid off workers age 30 to 50 rose from 44 to 56 percent.
} 
thought that layoffs were a permanent problem.

To determine whether jobs have become less stable in the 1990s, economists have examined household data from nationally representative surveys, focusing on mobility and job tenure. For the most part, these studies find only small changes in job mobility and employment tenure. The difference between public perception, largely based on media accounts of layoffs at large companies, and statistical evidence, using representative national samples of workers, can be rationalized in two ways: either the media accounts are anecdotes that would not add up consistently when viewed from a more systematic framework (a conclusion reached by Neumark and Polsky (1998)) or the statistical studies have missed something big because they have not properly looked at some of the variables emphasized in popular discussions.

This paper provides the first detailed analysis of job stability in large corporations in the 1990s, paying particular attention to the situation of midcareer workers. Given the public perception of rising instability in worker-firm attachments and the emphasis on large firms in media accounts, this paper starts with a basic question: in large firms, what has happened to employer tenure and the percentage of workers in long-term jobs in the 1990s? This is a measurement issue, which we address with a data set consisting of 51 large firms that are clients of Watson Wyatt Worldwide. Some of the firms in this sample have been included in media accounts of downsizing. If job security for workers at the peak of their careers in large firms has become a relic of labor history, then one would expect to see noticeable changes in the tenure distribution and in the percentage of persons in long-term jobs in this sample - if not across-theboard, certainly in firms that have downsized over the sample period.

This paper begins in Section 2 with a brief review of recent empirical studies of tenure and 
mobility, followed by a theoretical discussion in Section 3 of why firms might have changed their decision rules for layoffs in the 1990s. The leading explanations are a change in the way the stock market reacts to layoff announcements or an increased incentive to substitute younger for older workers. Section 4 explains some unique features of our data set and assesses its strengths and limitations. Summary statistics are discussed in detail, as they go to the very heart of the matter of what has happened to job stability in large firms in the 1990s. But such statistics can only take us so far. Simple comparisons between growing and downsizing firms will be misleading if employment growth is correlated with other key determinants of job stability such as labor cost and simple comparisons say nothing at all about age-substitution. Section 5 reports regression analysis that provides more definitive results on these issues. Section 6 summarizes the key results and discusses some unresolved issues.

\section{Conflicting perceptions}

It seems obvious: tenure is declining, jobs are riskier, retention rates are falling, and mobility is increasing. To be convinced of these trends, one need only read the newspapers (e.g., New York Times (1996)), any business magazine (e.g., Pennar (1996) in Business Week, Lieber (1996) and Munk (1999) in Fortune), or some of the numerous trendy books (e.g., Bluestone and Harrison (1986), Belous (1989), Moore (1996), and Reich (1997)) analyzing the changing business environment in the U.S. Generally, these reports are based on specific instances of individual firms announcing layoffs, downsizing, or closings. Most of the firms described in these reports are very large, nationally known corporations. Most of the job losers described in these accounts are workers in their 40s and 50s who had a long-term attachment with their employer. After reading enough of these reports, it is easy to become convinced that there is a new reality in 
the U.S. labor market -- workers must anticipate more frequent job changes, constant fear of being laid off, and the inability to retain a career job for much of their worklife.

Is this perception of U.S. labor market fact or fiction? The perception is based on news accounts of the actions of large firms; firms with fewer than 10,000 employees rarely appear on the cover of Newsweek. There has been no effort to systematically aggregate the experience of large firms into a general pattern of change. Instead, the accumulation of reports is taken as confirmation of the increase in instability; that is, enough media accounts presenting examples of layoffs by large employers provides a representative picture of the 1990s labor market.

To test the validity of this perception, economists have examined survey data on job duration and job changes, using data sets such as the Current Population Survey (CPS) or the Panel Survey of Income Dynamics (PSID) that are representative of the entire labor market. These surveys include employees from firms of all size categories. Studies based on these surveys have not attempted to focus on large firms, in part because the data often do not include measures of firm size and in part because of the difficulties in making comparisons across time within firm size categories with repeated cross sections. A brief summary of these studies is not consistent with the popular belief that employment tenure has sharply declined and job mobility has increased during the past two decades.

(1) Employer tenure: McGill, et al. (1996) compared median years in current job for men and women by age groups between 1951 and 1991 and concluded "disaggregation of the historical data on worker tenure does not support the general notion that workers have become inherently more job mobile in recent years." Their analysis used job tenure by age-sex group as reported in various government publications. The data showed that the median years in the 
current job for men in each age group were higher in 1991 than in 1966. Median years in the current job for women were also higher in each age group. Subsequent tabulations of the February 1996 CPS by the U.S. Bureau of Labor Statistics (1997) indicate that median years of tenure for men declined by 0.1 years between 1991 and 1996, but median tenure for women rose by 0.3 years.

(2) Percentage of workers in long-term jobs: Farber (1997) finds that the proportion of men reporting long-term jobs (more than 10 years or more than 20 years) declined slightly between 1979 and 1993 and then more substantially between 1993 and 1996. In contrast, there was a small increase in the proportion of women reporting long-term employment relationships. Farber concludes, "the structure of the employment relationship in some areas may have changed toward a model with less long-term job security. However, the analysis of the data on displaced workers suggests that, to the extent that this has occurred, the mechanism may not be to target high-tenure workers for layoff but may be to structure the base employment relationship different ways earlier in jobs."

(3) Mobility: Studies comparing the distribution of employer tenure across different waves of the CPS show job mobility has remained relatively constant over the past two decades. Diebold, Neumark, and Polsky (1997) report that retention rates declined slightly from 0.544 between 1983-87 to 0.530 between 1987-1991 and when retention rates are adjusted for the business cycle, the decline in retention rates is only from 0.537 to 0.527 . They report, "the most important conclusion to emerge from our study is the approximate stability of aggregate job retention rates over the 1980s and early 1990s.....Taken as a whole, the evidence from 4-year job retention rates estimated over this period does not point toward a secular decline in job stability." 
Extending this work through 1995, Neumark, Polsky and Hansen (1997) found that the four-year retention rate for all workers was slightly higher for 1991-95 (0.544) than for 1987-91 and 198487.

Findings from research using the PSID are more diverse. Rose (1996) finds increases in job turnover in the 1980s compared to the 1970s, whereas Polsky (1996), comparing 1976-81 to 1986-91, finds no evidence of a change in the likelihood of job separation. Jaeger and Stevens (1998) and Gottschalk and Moffitt (1998) carefully examine the PSID data and benchmark it against the CPS and SIPP, respectively. Their studies both conclude that there has been no trend toward increased job stability.

None of these studies using household surveys has been able to distinguish among workers based on the size of their employers. Thus, one possible explanation for the difference in perceptions is that the press accounts have concentrated on the actions of large firms while the research studies have examined all workers. Since almost 60 percent of all workers are employed by firms with fewer than 1,000 employees, this distinction could be very important in explaining the different conclusions concerning trends in job tenure and mobility. The popular perception of greater instability in large firms could be consistent with the academic findings of no overall change in stability if jobs in large (small) firms have become less (more) stable. This study provides direct evidence on job stability for large employers in the 1990s using the best possible data - firm employment records.

The measures of job duration used in this study all come from company payroll records that are used in conjunction with their compensation systems. Payroll records are not subject to any of the sources of erroneous measurement of employer tenure found in household surveys: 
imperfect recall by the worker, guesstimates by other household members on behalf of the worker, and rounding errors. ${ }^{3}$

Household survey data are not well suited for examining labor market policies of large employers. Firm size is not regularly included in household surveys, so inferences have to be drawn by comparing tenure distributions at two points in time. Comparing the number of employees with $\mathrm{x}$ years of tenure in year $\mathrm{t}$ in large firms to the number with $\mathrm{x}+\mathrm{n}$ years of tenure in year $\mathrm{t}+\mathrm{n}$ in large firms is problematic in a household survey for two reasons: (1) errors in reporting employment levels and (2) movement of firms over and under the thousand-employee threshold during the $\mathrm{n}$ years. Employer data will provide much more accurate measures of changes in the tenure distribution.

Another big advantage of employer data is that it permits an in-depth examination of firms that are changing size. Of special interest to the current debate is the ability to focus on large firms that are shrinking and to distinguish their behavior from firms that are growing. Press accounts of reductions in force usually emphasize cuts in the total number of jobs. But what actually happens in large companies undergoing, say, a 10 percent reduction in force? Are firms reacting to adverse economic events by pushing more expensive, older workers out the door or are they responding by reducing or halting the hiring of new employees? To answer this question, one must have data from employers to be able to determine retention rates by age and tenure and to calculate the cost of employing workers at various age and tenure levels.

The advantages of using employer data to examine labor market practices do not come without costs. One issue is whether the firms in any sample are representative of large employers

\footnotetext{
${ }^{3}$ For a full discussion of such errors, see Diebold, Neumark, and Polsky (1996).
} 
that have traditionally offered lifetime jobs. To address this concern, we present as much descriptive detail about the firms as possible and compare their characteristics to known values of key traits from national data. Nonetheless the results of this study should be interpreted as a case study of 51 firms with almost a million employees that may or may not be generalizable across all large firms. An additional limitation of the sample used here is that the information on worker characteristics is limited to age, tenure, and compensation. Although this prohibits any breakdowns by schooling, gender, or race, it should not produce any bias in our estimates; pay level can be used to control for variations in skill.

\section{Theoretical framework}

Tenure distributions and mobility decisions in each firm reflect the joint decision making of the firm and its employees. Firms base decisions about the size and composition of their labor force on demand for the firm's product, production technology, the cost of hiring and training workers, the cost of firing workers, and the cost and substitutability of various types of labor and other inputs. In addition to comparing current and expected future costs and productivity, firms take into account strategic considerations, including the value of the ability to write contracts for long-term jobs. Employees base their decisions on employment opportunities elsewhere in the labor market relative to those in the firm, as well as on the perceived value of nonmarket activities.

To understand possible changes in the 1990s in long-term employment contracts, a model must be able to explain why a firm would consider reneging on such a contract and why employer behavior in the 1990s would differ from earlier decades. Traditionally firms have employed a combination of FIFO layoffs and early retirement policies to reduce the number of workers. This 
practice is explained by a simple model of specific human capital in which the worker and the firm share the investment costs and the expected returns from increased productivity following training. ${ }^{4}$ During the training period, workers are paid less than the wage they are offered by competing firms (the investment cost to the worker) but more than the value of what they produce net of training costs (the investment cost to the firm). After training is completed, workers are paid less than the value of their output (firm return on investment) but more than their alternative wage (worker return on investment).

At the initial point of the employment relationship, there are no rents from training accruing to either party. As training continues, the present value of rents over time (for the worker, the firm, and both rents combined) follows a quadratic pattern. This pattern occurs because the remaining length of the investment period (a period of net costs to the worker and firm) is declining, some investment costs have already been made and thus, are now viewed as fixed costs. In addition, the length of time remaining in the training period is declining so that the time until positive investment returns for both the worker and the firm are expected is also declining.

The present value of future rents for each party reaches a maximum at the end of the training period and then begins to decline. During this period, output is greater than compensation which is greater than the compensation that workers could earn with their current skills at other firms. As years go by, the present value of rents for the remaining work life with the firm decline and eventually become zero at the end of the relationship.

With an adverse shock to the firm that is neutral across age and tenure categories, the

\footnotetext{
${ }^{4}$ The discussion here follows closely the exposition in Lazear $(1995,1998)$.
} 
entire rent profile shifts downward. The present value of future rents becomes negative at the tails of the tenure distribution. This would dictate a downsizing strategy focusing on the most junior and most senior employees. Firms would use a combination of first-in-first-out (FIFO) layoffs and buyout packages for more senior workers, with the mix depending on the shape of the tenure distribution and the size of the shock. In this framework, the only rationale for eliminating midcareer employees generating peak rents would be a shock that is biased to be more severe for, say, the top half of age/tenure distribution than for the bottom half.

Downsizing strategies dictating layoffs of midcareer workers can be explained in the context of Lazear's (1979) model. Even in good times, the present value of future rents is negative for all workers beyond a certain tenure level and is most negative for the most senior workers. Normally firms resist the temptation to layoff the most senior workers because they want to maintain a good reputation in the labor market, meaning simply that they value the option of writing more such productivity-enhancing contracts in the future. Yet in some situations, such as a decision to permanently drop product lines, outsource operations or implement labor-saving technology, an endgame situation arises where reputational concerns are overshadowed by the prospect of increased profitability. In such cases layoffs of midcareer employees would be economically rational for the firm, regardless of the implicit contract (and stock options can be used to offset the concerns of the remaining, younger employees).

This still leaves the question of why layoffs of high-tenure workers in large firms started to attract attention in the $1990 \mathrm{~s}^{5}$ One possibility is the connection between layoff announcements, stock value, and CEO pay. In an issue of Newsweek with its cover filled with CEOs labelled

\footnotetext{
${ }^{5}$ See Capelli (1998) for a broader survey and an empirical analysis of which firms were most likely to downsize.
} 
“Corporate Killers," Sloan (1996) proclaimed: “Once upon a time, it was a mark of shame to fire your workers en masse. It meant you had messed up your business. Today, the more people a company fires, the more Wall Street loves it, and the higher the stock price goes." Theoretically the impact of such announcements on stock prices is indeterminate (Worrell et al. (1991)). They could have a neutral effect if the company's problems were well known and the layoffs were expected and a negative effect if the layoffs were not expected or greater than expected. ${ }^{6}$ For the reaction to be positive (the popular perception today), the market must interpret the news as a sign that the firm was no longer in denial and was making the appropriate correction.

If there has been a shift in market reactions to layoff announcements, then there will be a corresponding change in the reward structure for CEOs which would make them more inclined to downsize. ${ }^{7}$ Firms would be willing to abrogate implicit contracts for lifetime jobs if the gains in shareholder wealth offset the losses in specific human capital and reputation in the labor market. In our data set this would show up in a comparison of growing and downsizing firms or in a model where turnover for workers in different tenure categories is a function of employment growth. If they were breaking implicit contracts, downsizing firms not only would have higher turnover overall, but also higher turnover (relative to growing firms) across all tenure categories, including mid-career employees. The alternative possibility is that downsizing firms still rely on FIFO layoffs and early-retirement buyouts, in which case turnover rates would vary at the extremes of the tenure distribution but not in the middle.

\footnotetext{
${ }^{6}$ Ironically, in earlier decades layoff announcements were seen as a signal of corporate distress and this was the basis for some of the opposition to the Worker Adjustment and Retraining Notification Act (Worrell et al 1991).

${ }^{7}$ Hallock (1998) finds small, negative effects of layoff announcements on share prices and no effect on CEO pay. Worrell et al. (1991) find stock prices go down after layoff announcements; Cascio et al. (1997) found no overall effect of downsizing on stock returns, but firms combining downsizing with asset restructuring received higher returns.
} 
A second theory for greater job instability involves substitution of younger for older employees. In a recent story in Fortune titled "Finished at Forty," Munk (1999) writes

Since the early 1980s big companies have been getting rid of people. For a long time, though, seniority mattered. Hierarchy was respected too. If people had to be fired, the younger, junior people were usually the first to go. That's no longer true. ... There's no way to tell how many of these people are over 40, but this much is sure: Companies today have less and less tolerance for people they believe are earning more than their output warrants. Such intolerance, or pragmatism, hits older workers hardest. The older an employee, the more likely it is he can be replaced by someone younger who earns half as much.

Theoretically, the incentive to substitute younger for older workers is affected by the slope of the tenure-compensation profile relative to the tenure-productivity profile. Greater global competition or an increased pace of technological change dictates a need for a more flexible workforce, according to some management experts. This makes young employees more attractive in the 1990s because they would supposedly be more willing to relocate or put in long hours than an older generation juggling child and elder care. The experience-productivity profile also could have flattened as a result of the increasing use of information technology, assuming that younger workers are more computer-savvy. The slope of the experience-productivity profile is not observable, so we focus empirically on the impact of the steepness of the pay profile. It is well established that wage differentials by experience have widened in the 1980s and 1990s, which would create a rationale for substituting inexperienced for midcareer workers.

Finally, initial conditions matter. A firm with a relatively large percentage of low-tenure employees is capable of adjusting to an adverse shock through FIFO layoffs without terminating any midcareer employees. A firm with very few recent hires does not have this option. To control for this, we report data by seniority categories and controls for the share of the most junior ( 0 to 4 ) and most senior (25 and up) employees in $\mathbf{t - 5}$ in regression models of turnover.

As pointed out by Gokhale, Groshen, and Neumark (1995), there also can be an 
interaction effect between profile steepness and initial conditions. A firm faced with a large percentage of older workers and a steep profile would obtain more cost savings through agesubstitution than a firm with the same percentage of older workers and a flat profile. We tested for such an effect in our data and were unable to reject the null hypothesis. To make the presentation of the empirical results more compact and easy to follow, these results are not reported.

Empirically, this study proceeds in the following fashion. First, we examine how tenure distributions have changed in our sample of firms in the 1990s. Once we get beyond the basic facts on tenure in the early and middle parts of the decade, we attempt to interpret these facts in light of the concern about rising job instability. It is difficult to draw inferences about job stability from simple comparisons of tenure distributions within a firm. An increase in mean tenure does not imply that workers are sticking around; such an increase will also occur if the firm downsizes and fires all junior employees. Similarly a decrease in mean tenure could reflect a situation where a growing firm has extremely low turnover accompanied by an increase in the percentage of new employees or a situation where midcareer and senior employees have been replaced by younger workers. Accordingly, we shift attention to the retention rate of workers in different ranges of the tenure distribution. Retention in this study is measured by comparing the age and tenure distribution at two points in time; the reasons behind the observed attrition in each age-tenure cell (quits, layoffs, disability, death) are not reported. In addition to the slope of the pay profile and the initial distribution of tenure, we model retention on the following variables:

Growing versus downsizing: Worker-initiated decisions on retention will be based on the difference in the expected value of opportunities within and outside the firm. Because of greater 
opportunities for promotions and higher-paying positions within growing firms, such firms should have fewer quits than shrinking firms. Layoffs can occur in both growing and shrinking firms, but are obviously more likely in the latter. Thus one would expect retention rates to increase with employment growth.

Downsizing can be done in a variety of different ways and this choice will have important implications for retention and tenure. Firms that reduce employment through hiring freezes should have higher retention rates and a greater proportion of workers with long tenure than firms that target midcareer and senior workers for layoffs. By looking not just at overall retention rates, but also at retention rates by seniority, this study will be able to give a fuller accounting of what happens to job stability after downsizing.

Pay level: The level of compensation also will influence decision making by both workers and employers. Firms with high wages are likely to have fewer quits, holding worker alternatives constant; they also are likely to have a greater incentive for headcount reductions, holding productivity constant. Most studies of mobility do find a positive association between wages and job duration, absent controls for alternative wages and productivity.

Firm size: Company size also should influence retention rates and the incidence of longterm jobs. Even among large firms, the companies with the most employees are more likely to have greater opportunities internally, and thus greater retention of employees.

\section{Data and summary statistics}

This study examines changes in job tenure in the 1990s using employment and compensation information on 51 firms. All of the firms are in the private sector, operate on a for- 
profit basis, and were consulting clients of Watson Wyatt Worldwide (WWW). WWW is an international benefit consulting firm that provides a variety of services associated with the development and maintenance of compensation systems to firms in all sectors of the economy. WWW markets its services to a wide range of firms; however, most of its clients tend to be firms with 1,000 or more employees. Most major corporations in the U.S. use some of their services. These employers are all relatively large firms ranging in size in the initial year from slightly less than 1,000 employees to almost 200,000 employees. Each of the firms has a defined benefit pension plan and all of the firms provide health insurance to their employees. The employers are from the manufacturing, financial, health, transportation, telecommunications, utility, and information sectors of the economy. These firms do not constitute a random sample of employers but they are a collection of firms that provide high pay, excellent benefits, and a tradition of providing long-term employment - exactly the type of firm that has been singled out in media accounts. The data set was developed by the Research and Information Center of Watson Wyatt Worldwide in an effort to help clients understand the impact of an aging labor force on individual firms. The firms included in the data represent companies for whom Watson Wyatt has already conducted such an analysis, for whom all relevant data were available. ${ }^{8}$ Cases were dropped when (1) there were obvious inconsistencies (e.g., retention rates of 125 percent) or (2) when there had been a major acquisitions or selloffs that precluded a full accounting of employment in all lines of business before and after the restructuring.

\footnotetext{
${ }^{8}$ Several studies by Watson Wyatt (Schieber and Graig (1995) and McDevitt and Schieber (1996)) analyze the general aging of the workforce and its implications on the cost and provision of benefits, especially retiree health benefits. The company developed an analytical model, called the Aging Diagnostic, to estimate the cost of aging on compensation costs at the individual firm level. This tool was applied to data either as a part of routine ongoing work done for Watson Wyatt clients or done to make an employer aware of issues raised in the two published reports.
} 
The data set includes information on the number of workers employed by age and tenure for each firm for two years. In each case, the years are five years apart; however, the five-year period of analysis varies somewhat across the firms, with 24 firms reporting data for 1990-1995, 25 firms reporting data for 1991-1996, and 2 firms reporting data for 1992-1997. Age-tenure retention rates between the two years are provided along with age-tenure levels of total compensation for the most recent year. In addition, the data provide age-tenure information concerning pay, health costs, pension costs, and the cost of paid leave.

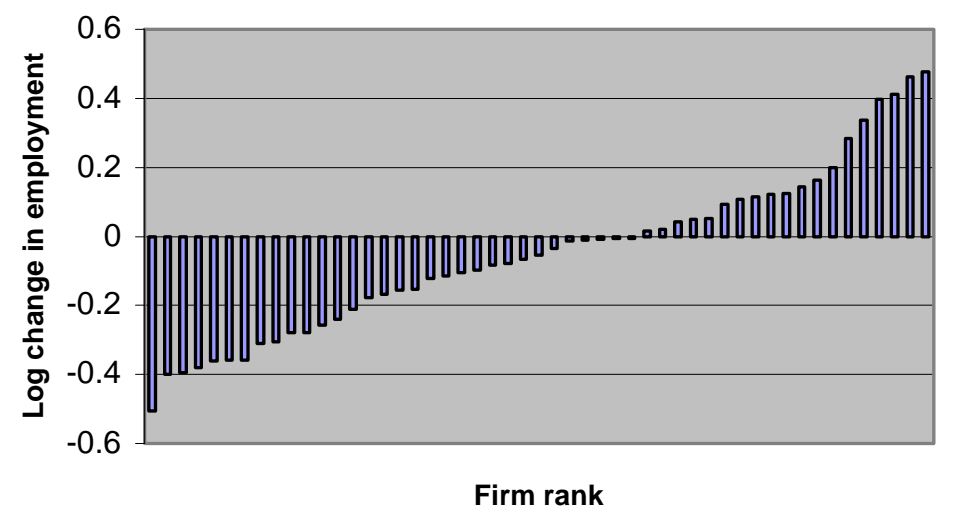

Figure 1. Log Change in Employment over 5-Year Study Period

Figure 1 shows the percentage change in employment levels for firms between the two years. Most firms (63 percent) reduced employment. Total employment among these companies contracted by 19.5 percent from 938,105 to 755,401 . The aggregate decline in employment was concentrated in the three largest firms; eliminating these three, total employment among the other 48 firms declined by 4.6 percent. The median percentage change in employment for these employers was -5.4 percent; the unweighted average change in employment was -2.0 percent. 
Table 1. Selected Characteristics of Sample

\begin{tabular}{|c|c|c|c|c|c|c|c|}
\hline Firm size & $\begin{array}{l}\text { Under } \\
1,500\end{array}$ & $\begin{array}{c}1,500 \text { to } \\
2,499\end{array}$ & $\begin{array}{c}2,500 \text { to } \\
4,999\end{array}$ & $\begin{array}{c}5,000 \text { to } \\
9,999\end{array}$ & $\begin{array}{c}10,000 \text { to } \\
19,999\end{array}$ & $\begin{array}{c}20,000 \text { to } \\
79,999\end{array}$ & $\begin{array}{l}80,000 \\
\text { or more }\end{array}$ \\
\hline Number of firms & 8 & 7 & 8 & 9 & 10 & 6 & 3 \\
\hline Number of firms with & & & & & & & \\
\hline Increased employment & 6 & 4 & 2 & 4 & 3 & 0 & 0 \\
\hline $\begin{array}{l}\text { Percentage change in } \\
\text { Employment }\end{array}$ & 11.8 & 3.9 & -9.8 & 5.8 & 3.1 & -14.7 & -32.3 \\
\hline
\end{tabular}

Table 1 presents key employment data for the firms by level of employment. Generally, total employment among the smaller employers was growing, with the most rapid growth reported in the very smallest category. Employment among the largest employers was contracting, with the most significant contraction occurring among the very largest firms.

One would not expect worker characteristics in the large firms examined here to exactly match those found in household surveys. All but one of the firms in this sample has 1,000 or more employees. All provide health insurance and retirement benefits. They are not evenly distributed across industries. Most of the firms are in manufacturing, transportation, communications, utilities, financial services, and health services. None are in agriculture, mining, construction, wholesale trade, and services outside of health care. With these provisos in mind, we examined the April 1993 CPS, which contains a supplemental Survey of Employee Benefits and is the only large household survey that falls within our sample period and contains information on firm size and employee benefits (availability of health insurance and retirement plans and participation in those plans). To re-weight the CPS so that it resembles our sample as closely as possible, we dropped all observations where (1) the respondent works in a firm with fewer than 1,000 employees, (2) the respondent is not covered by the employer's health insurance and 
retirement plans, and (3) the respondent works for the government. Average age was 40.9 in the first year of the employer sample, which is reasonably close to the value of 40.4 in the CPS matched sample. Tenure in the employer sample in year $\boldsymbol{t}$ averaged 12.3 years, slightly higher than the value of 11.6 years in the CPS. The only dimension in which the two samples do not match up very well is in terms of pay. Pay levels in the employer sample in year $t+5$ average $\$ 44,521$, whereas estimated annual salary in the CPS (52 times weekly salary) is $\$ 35,318$. The pay discrepancy may result from differences in industry mix between the CPS and the WWW sample or underrepresentation of very large firms in the CPS.

To summarize, the firms in the WWW sample look very much like the type of firm that has been featured in today's headlines - high pay, generous benefits, and long job durations, at least as compared to the overall labor market. We do not maintain that this is a totally representative sample of such firms, but the sample is certainly large and diverse enough to be an informative "mega-case study" of employment practices in large corporations in the 1990s. As a practical matter, the type of data examined here is only available directly from the firm and is so highly sensitive that few firms are likely to be willing to respond to requests from academics for this type of information. To get a critical mass of data points, collaborative ventures between academics and compensation experts in the private sector are currently the only way for getting this type of research done.

Have long-term jobs vanished in the 1990s? Our analysis begins by examining several key indicators of job stability including average years of tenure, percentage of workers with 10 or more years of service, percentage of workers with 20 or more years of service, and the firm's retention rate. In each case, the data are reported for the entire sample and separately by firm 
size. Summary statistics on the incidence of long-term jobs in the 1990s are reported in Table 2.

We report unweighted and weighted (by employment in year $t$-5) averages for the entire sample, along with weighted averages by size class. The key findings are as follows:

Table 2. Summary statistics on tenure, age, and retention rates, overall and by firm size

\begin{tabular}{|c|c|c|c|c|c|c|c|c|c|}
\hline Firm Size & $\begin{array}{c}\text { All, no } \\
\text { weights }\end{array}$ & $\begin{array}{c}\text { All, } \\
\text { weighted }\end{array}$ & $\begin{array}{l}\text { Under } \\
1,500\end{array}$ & $\begin{array}{l}1,500 \text { to } \\
2,499\end{array}$ & $\begin{array}{c}2,500 \text { to } \\
4,999\end{array}$ & $\begin{array}{c}5,000 \text { to } \\
9,999\end{array}$ & $\begin{array}{c}10,000 \text { to } \\
19,999\end{array}$ & $\begin{array}{c}20,000 \text { to } \\
79,999\end{array}$ & $\begin{array}{l}80,000 \\
\text { or more }\end{array}$ \\
\hline $\begin{array}{l}\text { Average age in } \\
\text { initial year }\end{array}$ & 39.9 & 40.7 & 41.2 & 40.5 & 39.7 & 38.2 & 38.6 & 41.2 & 41.5 \\
\hline $\begin{array}{l}\text { Change in } \\
\text { average age }\end{array}$ & 1.4 & 1.2 & 1.4 & 1.0 & 1.7 & 1.2 & 1.7 & 1.1 & 1.0 \\
\hline $\begin{array}{l}\text { Average tenure in } \\
\text { initial year }\end{array}$ & 10.4 & 12.6 & 11.2 & 10.5 & 10.8 & 8.5 & 9.1 & 11.3 & 14.6 \\
\hline $\begin{array}{l}\text { Change in } \\
\text { average tenure }\end{array}$ & 0.9 & 0.8 & -0.4 & 0.5 & 1.4 & 0.7 & 1.8 & 1.3 & 0.5 \\
\hline $\begin{array}{l}\text { Percentage with } \\
10+\text { years tenure } \\
\text { in initial year }\end{array}$ & 44.7 & 54.5 & 46.8 & 48.6 & 48.1 & 34.5 & 37.6 & 48.7 & 64.4 \\
\hline $\begin{array}{l}\text { Change in } \\
\text { percentage with } \\
10+\text { years tenure }\end{array}$ & 3.6 & 4.1 & -1.4 & -2.0 & 4.6 & 2.8 & 8.3 & 8.3 & 1.8 \\
\hline $\begin{array}{l}\text { Percentage with } \\
20+\text { years tenure } \\
\text { in initial year }\end{array}$ & 16.7 & 25.6 & 19.4 & 13.8 & 17.8 & 11.4 & 12.9 & 19.6 & 34.0 \\
\hline $\begin{array}{l}\text { Change in } \\
\text { percentage with } \\
20+\text { years tenure }\end{array}$ & 2.1 & 0.6 & -1.9 & 2.9 & 5.7 & 0.5 & 4.1 & 1.3 & -1.0 \\
\hline $\begin{array}{l}\text { Five-year retention } \\
\text { rate (percentage) }\end{array}$ & 67.9 & 60.7 & 76.3 & 70.5 & 64.5 & 63.8 & 70.7 & 67.6 & 54.4 \\
\hline
\end{tabular}


1. The average duration of employee-employer matches in our sample of large firms is longer in the mid-1990s than in the early 1990s. Average tenure in the early 1990s was 12.6 years and increased by 0.8 years over the next five years.

2. The increase in tenure was far from uniform across our sample. In 12 firms, average tenure declined and it was unchanged in one firm. Average tenure increased by two years or more in 11 firms.

3. Average tenure rose across all size categories, except for firms with fewer than 1,500 employees. The increase in average tenure was smallest in the very largest category (where all three firms underwent significant reductions in force) and the 1,500-to-2,499-employee category.

4. The percentage of workers who have been with the same employer 10 or more years increased considerably in the 1990s. On average, 54.5 percent of employees had 10 or more years of service in the early 1990s; this increased by 4.1 percentage points over the next five years.

5. The percentage of workers who have been with the same employer 20 or more years also increased in the 1990s. On average, 25.6 percent of employees had 20 or more years of service in the early 1990s; this increased by 0.6 percentage points over the next five years.

6. About three-fifths (60.7 percent) of the workers in our sample stayed with the same employer over the entire five-year sample period.

7. Average age of workers was 40.7 in the early 1990s and increased by 1.2 years over the next five years. Average age increased by one year or more in every size category.

Retention rates by tenure category The employment records indicate that average tenure and age 
of employees for these 51 large firms increased in the 1990s. As noted above, this does not mean job stability has increased. A breakdown of retention rates by tenure category is necessary to understand whether tenure is rising because everyone is staying or because many junior and midcareer employees have been laid off. With data on employment by tenure category, we calculate retention rates by years of service to show the rate at which workers stay with the firm at different stages of their career.

As shown in Table 3, the five-year retention rate is lowest among employees with 20 or more years of service, presumably reflecting high retirement rates among these workers. Retention rates across the entire sample rise with seniority through 15 -to-19 years of service, a pattern that is consistent with the findings of the mobility literature and reflect job shopping, firstin-first-out (FIFO) layoffs, and perhaps up-or-out contracts. Over 70 percent of mid-career employees (10 to 19 years of service in year $\boldsymbol{t}-5$ ) stay with the firm for another five years. However in the two smallest size categories (less than 1,500 employees and 1,500 to 2,499 employees), retention is greatest among the most junior employees, which most likely reflects opportunities for advancement created by rapid growth in these firms.

Table 3. Retention rates by tenure category and firm size

\begin{tabular}{lcccccccc}
\hline Seniority & $\begin{array}{c}\text { All, } \\
\text { Weighted }\end{array}$ & $\begin{array}{c}\text { Under } \\
1,500\end{array}$ & $\begin{array}{c}1,500 \text { to } \\
2,499\end{array}$ & $\begin{array}{c}2,500 \text { to } \\
4,999\end{array}$ & $\begin{array}{c}5,000 \text { to } \\
9,999\end{array}$ & $\begin{array}{c}10,000 \text { to } \\
19,999\end{array}$ & $\begin{array}{c}20,000 \text { to } \\
79,999\end{array}$ & $\begin{array}{c}80,000 \text { or } \\
\text { more }\end{array}$ \\
\hline 0 to 4 & 60.8 & 92.5 & 83.9 & 63.6 & 62.3 & 76.2 & 72.0 & 51.0 \\
5 to 9 & 63.7 & 80.4 & 74.7 & 68.5 & 66.7 & 68.2 & 73.7 & 57.7 \\
10 to 14 & 70.2 & 78.8 & 62.4 & 74.3 & 70.9 & 73.3 & 78.0 & 66.4 \\
15 to 19 & 71.1 & 76.3 & 61.2 & 70.5 & 70.0 & 73.5 & 74.5 & 69.5 \\
20 \& up & 48.1 & 56.1 & 49.9 & 55.1 & 52.8 & 59.5 & 50.7 & 42.9 \\
All & 60.7 & 76.3 & 70.5 & 64.5 & 63.8 & 70.7 & 67.6 & 54.4 \\
\hline
\end{tabular}


An important issue in terms of job security is how the pattern of retention rates across years of service compares in growing and shrinking firms. Retention rates should be smaller for shrinking firms because of greater odds of a layoff or an early-retirement buyout. Quits might also increase if workers have opportunities elsewhere. If the implicit contract of job security for midcareer employees has been abrogated in the 1990s, one would expect to see much smaller retention rates for those with 10 to 19 years of service in shrinking firms than in growing firms. On the other hand, it is conceivable that shrinking firms have used the standard methods of FIFO layoffs and early-retirement buyouts to downsize their workforce.

As expected, Table 4 shows a very large difference in weighted retention rates between growing and downsizing firms - 69 percent of all employees stay for five additional years in growing firms versus only 59.8 percent in shrinking firms. Despite this overall disparity in retention rates by employment growth, the retention rates for midcareer employees are virtually indistinguishable for growing and downsizing firms. This is true for both the weighted and

Table 4. Retention rates by seniority and employment growth

\begin{tabular}{lcccccc}
\hline Seniority & $\begin{array}{c}\text { Weighted, } \\
\text { employment } \\
\text { declining }\end{array}$ & $\begin{array}{c}\text { Weighted, } \\
\text { employment } \\
\text { growing }\end{array}$ & $\begin{array}{c}\text { Weighted, } \\
\text { difference }\end{array}$ & $\begin{array}{c}\text { Unweighted, } \\
\text { employment } \\
\text { declining }\end{array}$ & $\begin{array}{c}\text { Unweighted, } \\
\text { employment } \\
\text { growing }\end{array}$ & $\begin{array}{c}\text { Unweighted, } \\
\text { Difference }\end{array}$ \\
\hline 0 to 4 & 59.0 & 76.0 & 19.0 & 70.4 & 78.2 & 7.8 \\
5 to 9 & 63.3 & 67.2 & 3.9 & 69.2 & 72.7 & 3.5 \\
10 to 14 & 70.4 & 69.0 & -1.4 & 73.1 & 70.8 & -1.3 \\
15 to 19 & 71.2 & 70.3 & -0.9 & 70.5 & 71.6 & 1.1 \\
20 \& up & 47.0 & 57.8 & 10.8 & 52.7 & 54.7 & 2.0 \\
All & 59.8 & 69.0 & 9.2 & 66.2 & 70.6 & 4.2 \\
\hline
\end{tabular}


unweighted tabulations. All of the difference in aggregate retention rates results from lower retention for the most recent hires and the most senior employees. Job retention is the same for midcareer employees in downsizing companies as it is in growing companies.

How do retention rates in the large firms in our sample compare to those for the rest of the labor market? The most straightforward comparison is with the Neumark, Polsky, and Hansen (1997) finding of an overall retention rate of 54.4 percent for 1991-95. It is not especially surprising to see that the five-year retention rate for growing firms in the Wyatt sample is considerably higher. What may be surprising is that the five-year retention rate of 59.8 percent for the downsizing firms in the Wyatt sample is greater than the four-year retention rate for the entire labor market. From a purely statistical standpoint, a worker in the early 1990s had higher odds of staying with a large firm in the Wyatt sample that was going to decrease employment than they would have had in any job picked at random.

\section{Determinants of retention}

The data on retention imply that midcareer employees have been sheltered from downsizing in large firms in the 1990s, contrary to media accounts. A regression analysis allows us to control for other variables that are correlated with employment growth, especially labor costs and firm size, and also permits a test of one dimension of the age-substitution hypothesis. The retention rate was regressed on the following variables: log employment in $\boldsymbol{t} \mathbf{- 5}$, the change in $\log$ employment between $\boldsymbol{t}-5$ and $\boldsymbol{t}, \log$ compensation (including health care, defined benefit and defined contribution pensions, and paid time off), the steepness of the compensation profile (as measured by the log difference in compensation between those aged 45 to 49 with 20 to 24 years of tenure and those aged 25 to 29 with zero to four years of tenure), the percentage of workers 
with less than five years of service in $\boldsymbol{t}-\mathbf{5}$, and the share of workers with 25 or more years of service in $\mathbf{t - 5}$. To determine if the impact of these variables varied with seniority, a separate model was estimated for five different ranges of the seniority distribution. The results are reported in Table 5. To obtain a more in-depth view into decision making by workers and firms in the context of downsizing, separate models were estimated for growing and shrinking firms; these results are reported in Table 6.

Employment growth: As expected, retention rates increase with employment growth. A 0.1 increase in log employment growth is associated with a 5.6 percentage point increase in the retention rate. The impact of employment growth on retention is much greater for junior than senior employees. A 0.1 increase in log employment growth is associated with a 7.8 percentage point increase in the retention rate of employees with 0 to 4 years of service. In contrast, it is associated with just a 3.0 percentage point increase in the retention rate of those with 20 or more years of service. This indicates that seniority continues to be strongly associated with employment adjustment decisions by firms.

This conclusion becomes more robust when the sample is split by employment growth. In downsizing firms, the retention rate for workers with less than five years of service is much more sensitive to employment growth than the retention rate for more senior workers. A $0.1 \log$ decrease in employment is associated with a 9.1 percentage point drop in the retention of workers with less than five years of service, whereas it has no effect on retention of workers with 20 or more years of service. Although this result cannot be compared to patterns in earlier decades, it has a very clear and important implication for today's debate about job security: the impact of employment adjustment is still being borne by the most junior workers. 
Table 5. Retention rate regressions

\begin{tabular}{|c|c|c|c|c|c|c|c|}
\hline & $\begin{array}{l}\text { Mean } \\
\text { (S.D.) }\end{array}$ & $\begin{array}{c}\text { All } \\
\text { workers }\end{array}$ & $\begin{array}{c}\text { Tenure } \\
0 \text { to } 4 \\
\end{array}$ & $\begin{array}{c}\text { Tenure } \\
5 \text { to } 9\end{array}$ & $\begin{array}{c}\text { Tenure } \\
10 \text { to } 14 \\
\end{array}$ & $\begin{array}{l}\text { Tenure } \\
15 \text { to } 19 \\
\end{array}$ & $\begin{array}{c}\text { Tenure } \\
20 \text { and up }\end{array}$ \\
\hline Constant & & $\begin{array}{l}-0.981 \\
(0.528)\end{array}$ & $\begin{array}{l}-0.154 \\
(1.073)\end{array}$ & $\begin{array}{l}-1.265 \\
(0.958)\end{array}$ & $\begin{array}{l}-3.237 \\
(0.907)\end{array}$ & $\begin{array}{l}-2.698 \\
(1.067)\end{array}$ & $\begin{array}{l}-1.298 \\
(1.061)\end{array}$ \\
\hline $\begin{array}{l}\text { Percentage with } \\
\text { tenure } 0 \text { to } 4 \text { in t-5 }\end{array}$ & $\begin{array}{c}0.340 \\
(0.151)\end{array}$ & $\begin{array}{l}-0.613^{*} \\
(0.129)\end{array}$ & $\begin{array}{l}-1.089^{*} \\
(0.263)\end{array}$ & $\begin{array}{l}-0.449 \\
(0.235)\end{array}$ & $\begin{array}{l}-0.183 \\
(0.222)\end{array}$ & $\begin{array}{l}-0.085 \\
(0.262)\end{array}$ & $\begin{array}{l}-0.025 \\
(0.260)\end{array}$ \\
\hline $\begin{array}{l}\text { Percentage with } \\
\text { tenure } 25+\text { in t-5 }\end{array}$ & $\begin{array}{l}0.086 \\
(0.067)\end{array}$ & $\begin{array}{l}-0.284 \\
(0.254)\end{array}$ & $\begin{array}{l}-0.590 \\
(0.517)\end{array}$ & $\begin{array}{c}0.604 \\
(0.462)\end{array}$ & $\begin{array}{c}0.643 \\
(0.437)\end{array}$ & $\begin{array}{c}0.523 \\
(0.514)\end{array}$ & $\begin{array}{l}0.027 \\
(0.511)\end{array}$ \\
\hline $\begin{array}{l}\text { Log(total } \\
\text { compensation) }\end{array}$ & $\begin{array}{l}10.904 \\
(0.244)\end{array}$ & $\begin{array}{l}0.193^{*} \\
(0.049)\end{array}$ & $\begin{array}{c}0.160 \\
(0.100)\end{array}$ & $\begin{array}{l}0.203^{*} \\
(0.089)\end{array}$ & $\begin{array}{l}0.375^{*} \\
(0.084)\end{array}$ & $\begin{array}{r}0.318^{*} \\
(0.099)\end{array}$ & $\begin{array}{l}0.188 \\
(0.098)\end{array}$ \\
\hline $\begin{array}{l}\text { Log compensation } \\
\text { difference by age- } \\
\text { seniority }\end{array}$ & $\begin{array}{c}0.625 \\
(0.249)\end{array}$ & $\begin{array}{l}-0.250^{*} \\
(0.057)\end{array}$ & $\begin{array}{l}-0.317^{*} \\
(0.116)\end{array}$ & $\begin{array}{l}-0.024 \\
(0.103)\end{array}$ & $\begin{array}{l}-0.173 \\
(0.098)\end{array}$ & $\begin{array}{l}-0.202 \\
(0.115)\end{array}$ & $\begin{array}{l}-0.262^{*} \\
(0.114)\end{array}$ \\
\hline $\log \left(L_{t} / L_{t-5}\right)$ & $\begin{array}{l}-0.048 \\
(0.236)\end{array}$ & $\begin{array}{l}0.565^{*} \\
(0.059)\end{array}$ & $\begin{array}{r}0.775^{*} \\
(0.120)\end{array}$ & $\begin{array}{l}0.469^{*} \\
(0.107)\end{array}$ & $\begin{array}{l}0.396^{*} \\
(0.101)\end{array}$ & $\begin{array}{r}0.366^{*} \\
(0.119)\end{array}$ & $\begin{array}{l}0.298^{*} \\
(0.118)\end{array}$ \\
\hline $\log \left(L_{t-5}\right)$ & $\begin{array}{c}8.774 \\
(1.335)\end{array}$ & $\begin{array}{l}-0.004 \\
(0.009)\end{array}$ & $\begin{array}{l}-0.023 \\
(0.018)\end{array}$ & $\begin{array}{l}-0.012 \\
(0.016)\end{array}$ & $\begin{array}{c}0.001 \\
(0.015)\end{array}$ & $\begin{array}{c}0.008 \\
(0.018)\end{array}$ & $\begin{array}{l}-0.004 \\
(0.018)\end{array}$ \\
\hline $\begin{array}{l}\text { Mean (S.D.) of } \\
\text { dependent variable }\end{array}$ & & $\begin{array}{c}0.679 \\
(0.142)\end{array}$ & $\begin{array}{c}0.733 \\
(0.236)\end{array}$ & $\begin{array}{c}0.705 \\
(0.172)\end{array}$ & $\begin{array}{c}0.722 \\
(0.166)\end{array}$ & $\begin{array}{c}0.709 \\
(0.172)\end{array}$ & $\begin{array}{c}0.534 \\
(0.157)\end{array}$ \\
\hline $\begin{array}{l}\mathrm{R}^{2} \\
\text { Root MSE } \\
\mathrm{N}\end{array}$ & & $\begin{array}{c}0.758 \\
0.074 \\
51\end{array}$ & $\begin{array}{c}0.636 \\
0.151 \\
51\end{array}$ & $\begin{array}{l}0.454 \\
0.135 \\
51\end{array}$ & $\begin{array}{c}0.480 \\
0.128 \\
51\end{array}$ & $\begin{array}{c}0.324 \\
0.150 \\
51\end{array}$ & $\begin{array}{c}0.200 \\
0.150 \\
51\end{array}$ \\
\hline
\end{tabular}

Note: * indicates statistically significant at $\mathrm{p}=0.05$ or lower

Employment growth is also associated with higher retention rates in growing firms, but the impact is greatest at the extremes of the seniority distribution. The result for junior workers probably reflects the relatively greater internal opportunities for advancement in growing firms. The result for workers with 20 or more years of service is a bit more surprising, and most likely reflects the efforts of employers to delay retirement.

Pay level: Retention rates are greatest in the organizations with the highest pay levels. A 0.1 
Table 6. Retention rate regressions, by employment growth

\begin{tabular}{|c|c|c|c|c|c|c|}
\hline & All workers & $\begin{array}{c}\text { Tenure } \\
0 \text { to } 4\end{array}$ & $\begin{array}{c}\text { Tenure } \\
5 \text { to } 9\end{array}$ & $\begin{array}{c}\text { Tenure } \\
10 \text { to } 14\end{array}$ & $\begin{array}{l}\text { Tenure } \\
15 \text { to } 19\end{array}$ & $\begin{array}{c}\text { Tenure } \\
20 \text { and up }\end{array}$ \\
\hline \multicolumn{7}{|l|}{$\begin{array}{l}\text { Log (total } \\
\text { compensation) }\end{array}$} \\
\hline Growing firms & $\begin{array}{r}0.365^{\star} \\
(0.081)\end{array}$ & $\begin{array}{r}0.309^{*} \\
(0.154)\end{array}$ & $\begin{array}{c}0.142 \\
(0.205)\end{array}$ & $\begin{array}{c}0.568^{*} \\
(0.175)\end{array}$ & $\begin{array}{c}0.591^{*} \\
(0.215)\end{array}$ & $\begin{array}{c}0.504^{*} \\
(0.191)\end{array}$ \\
\hline Shrinking firms & $\begin{array}{c}0.084 \\
(0.065)\end{array}$ & $\begin{array}{l}-0.050 \\
(0.147)\end{array}$ & $\begin{array}{c}0.259^{\star} \\
(0.111)\end{array}$ & $\begin{array}{c}0.230^{*} \\
(0.114)\end{array}$ & $\begin{array}{c}0.160 \\
(0.131)\end{array}$ & $\begin{array}{c}0.058 \\
(0.139)\end{array}$ \\
\hline \multicolumn{7}{|l|}{$\begin{array}{l}\text { Log compensation } \\
\text { difference by age \& } \\
\text { seniority }\end{array}$} \\
\hline Growing firms & $\begin{array}{l}-0.164 \\
(0.084)\end{array}$ & $\begin{array}{l}-0.100 \\
(0.158)\end{array}$ & $\begin{array}{l}-0.034 \\
(0.212)\end{array}$ & $\begin{array}{l}-0.126 \\
(0.180)\end{array}$ & $\begin{array}{l}-0.135 \\
(0.221)\end{array}$ & $\begin{array}{l}-0.124 \\
(0.197)\end{array}$ \\
\hline Shrinking firms & $\begin{array}{l}-0.149 \\
(0.096)\end{array}$ & $\begin{array}{l}-0.026 \\
(0.217)\end{array}$ & $\begin{array}{c}0.096 \\
(0.164)\end{array}$ & $\begin{array}{l}-0.060 \\
(0.168)\end{array}$ & $\begin{array}{l}-0.315 \\
(0.194)\end{array}$ & $\begin{array}{l}-0.319 \\
(0.205)\end{array}$ \\
\hline \multicolumn{7}{|l|}{$\log \left(L_{t} / L_{t-5}\right)$} \\
\hline Growing firms & $\begin{array}{c}0.702^{*} \\
(0.162)\end{array}$ & $\begin{array}{r}0.750^{*} \\
(0.307)\end{array}$ & $\begin{array}{c}0.290 \\
(0.410)\end{array}$ & $\begin{array}{c}0.561 \\
(0.349)\end{array}$ & $\begin{array}{c}0.556 \\
(0.429)\end{array}$ & $\begin{array}{c}0.902^{*} \\
(0.381)\end{array}$ \\
\hline Shrinking firms & $\begin{array}{c}0.652^{*} \\
(0.086)\end{array}$ & $\begin{array}{r}0.912^{*} \\
(0.193)\end{array}$ & $\begin{array}{c}0.734^{*} \\
(0.146)\end{array}$ & $\begin{array}{r}0.661^{*} \\
(0.149)\end{array}$ & $\begin{array}{c}0.381^{*} \\
(0.173)\end{array}$ & $\begin{array}{c}0.178 \\
(0.182)\end{array}$ \\
\hline \multicolumn{7}{|c|}{$\begin{array}{l}\text { Each equation is estimated over a subsample of either } 19 \text { growing firms or } 32 \text { shrinking firms and } \\
\text { includes a constant, percentage with } 0 \text { to } 4 \text { years of tenure in } t-5 \text {, percentage with } 25 \text { or more } \\
\text { years of tenure in t-5, and log of employment in t-5 as independent variables. }\end{array}$} \\
\hline
\end{tabular}

increase in log compensation is associated with a 1.9 percentage point increase in the retention rate. Looking at the entire 51 firm sample, the impact of compensation on retention appears to be greatest for midcareer employees. However, as Table 6 indicates, compensation has much less impact on retention in shrinking than growing firms. Among growing firms, compensation is associated with higher retention in all but one tenure category and is greatest among the most senior employees. In shrinking firms, compensation is uncorrelated with overall retention rates, as well as retention rates for the least junior (tenure under five) and most senior (tenure 20 or more) 
employees. In these firms, retention will reflect a mix of quit and layoff decisions, making it a bit difficult to interpret the findings. The fact that compensation is associated with greater retention among workers with five to 14 years of service could reflect some degree of "job lock" (no exits despite uncertain future prospects) or confidence in the value of a long term relationship.

Pay differentials by age and tenure: Across the entire sample of firms, the overall retention rate is much lower in firms with the largest differentials in pay by age and seniority. A 0.1 increase in this log pay differential is associated with a 2.5 percentage point decrease in employee retention.

Does this mean that firms are making widespread substitutions of new hires for senior workers? If this were the case, the age-seniority gap in pay would have a much bigger effect on the retention of senior employees than on entry-level workers; in an extreme situation it could even have a positive coefficient for low-tenure employees. This is clearly not the case, as the results in Table 5 show that the impact of profile steepness on retention is nearly equal for employees in the 0-4 and 20+ tenure categories. Also, if age-substitution were a driving factor in today's downsizing patterns, the age-seniority gap in pay would have an impact on retention when the sample is restricted to downsizing firms. Instead, Table 6 shows no impact of profile steepness on retention among downsizing firms.

Other variables: The size of the organization in $t-5$ had no effect on retention. Although this runs counter to the prevailing wisdom that mobility should fall with size, keep in mind that all but one firm in this study had 1,000 or more employees in $t-5$. It could very well be that size has little to no effect beyond this threshold. Retention was much lower in firms with the largest shares of employees with less than five years of service. The firms with the largest shares of new 
hires in $t-5$ had much lower retention in that tenure bracket, but not in any other. This is suggestive of some sort of up-or-out contract in such firms. The share of very senior employees had no effect on retention rates overall or for any particular group.

\section{Conclusions and caveats}

One possible reason for the difference between the prevailing wisdom (rising job instability, especially for midcareer workers in large corporations) and the research literature (job stability has not changed all that much) is that the latter has not focused on large firms. This is the first study to use employer data to examine job stability in the 1990s, as well as the first to make distinctions in job stability by employer size and employment growth. We have learned the following:

- Job duration in large corporations continues to be much longer than in the rest of the labor market. This is true for every measure used in this study.

- There was a 61 percent probability that a worker in one of the large firms in our sample would be with the same employer five years later. This is about 7 percentage points higher than the odds for the entire labor market reported in Neumark, Polsky and Hansen (1997). Even in large firms with shrinking employment, the odds that a worker would be with the same employer five years later were higher than the same odds for the labor market as a whole.

- There is no evidence of a trend toward focusing on midcareer employees in the implementation of downsizing decisions. To the contrary, retention rates for workers with 10 to 19 years of service are virtually the same in downsizing and growing firms. Retention rates in downsizing firms tend to be lowest among the most junior and most senior employees, as predicted by human capital models. 
- Retention rates were much higher in firms with growing employment than in firms with shrinking employment. However, across all downsizing firms, the retention of junior employees is much more strongly affected by the degree of downsizing than the retention of senior employees.

- Firms with the largest pay differentials between younger, junior workers and older, senior workers have lower overall retention rates. However, a careful examination of how compensation profiles relate to retention in particular tenure brackets shows no evidence that such employers are substituting younger for older workers.

Even though employment declined in most of the companies in this study, the picture that emerges here is that jobs in large corporations in the 1990s continue to be much more stable than in the rest of the labor market and that this is especially true for midcareer workers.

This picture is consistent with other research by economists on job duration in that we do not find a sharp downward break during the 1990s. To reconcile our results with the prevailing wisdom is much more difficult. One possibility is that the firms in this study are not totally representative of the firms featured in media accounts: large firms with long-term job attachments and generous pay and benefits packages. Even though we have reported as much information as we can about these firms and even though some of the firms in our sample have been featured in media accounts of downsizing, ultimately this issue can only be resolved through further research that attempts to replicate and extend the findings of this study.

Another concern is that all of our data are for the 1990s, leaving open the question of how this experience compares to earlier decades. To address this issue, we extracted data for private sector employees aged 16 or higher from the May 1983 and April 1993 supplements to the 
Current Population Survey. These supplements were selected because they contained information on firm size and employee benefits. We estimated probit models of the odds of being in a longterm job (10 plus or 20 plus years of service) and a regression of years of service and used models that included a wide range of independent variables, including indicators of firm size. We found that there has been no change between 1983 and 1993 in the differential in length of service between firms with 1,000 or more employees and smaller firms or in the firm-size differential in the odds of being in a long-term job. If anything, the coefficients for the 1,000 plus category were slightly larger in 1993 than in 1983.

One aspect of job stability that this study does not address is the consequences of mergers and selloffs. According to data compiled by Securities Data Company reported in the Economist (1998), mergers and acquisitions were at record levels in 1997, with deals worth $\$ 957$ billion or 12 percent of GDP. This is well above the \$138 billion level (two percent of GDP) in 1991. M\&A activity in intervening years ranges between two and eight percent. Although this study cannot address job instability arising from restructuring, we should emphasize that much of the policy and media discussion of the issue has focused on firms that have not gone through mergers.

The other way of reconciling our results with the prevailing wisdom is to recognize that anecdotes are an imperfect substitute for data. We do not question that many individuals, families, and communities have been shattered by downsizing experiences in the 1990s. What we question is whether these well-publicized events reflect a widespread shift in the incidence of long-term jobs in large corporations. We have not found any evidence indicating such a shift so far. 


\section{REFERENCES}

Belous, Richard. 1989. The Contingent Economy: The Growth of the Temporary, PartTime and Subcontracted Workforce. Washington: National Planning Association.

Bluestone, Barry, and Bennett Harrison. 1986. The Great American Job Machine: The Proliferation of Low-Wage Employment in the American Economy. Washington: USGPO.

Cappelli, Peter. 1998. "Explaining the Incidence of Downsizing and the Effect on Performance," paper presented at Sage Foundation Conference on Changes in Job Stability and Job Security.

Cascio, Wayne F., Clifford E. Young, and James R. Morris. 1997. "Financial Consequences of Employment-Change Decisions in Major U.S. Corporations," Academy of Management Journal, Vol. 40, No. 5, pp. 1175-1189.

Church, George J. 1993. "Whatever Happened to the Great American Job?" Time November 22, 1993, pp. 34-39.

Diebold, Francis, David Neumark, and Daniel Polsky. 1997. "Job Stability in the United States," Journal of Labor Economics vol. 2, pp. 206-223.

Economist. "America Bubbles Over.” April 18, 1998, pp. 67-69.

Farber, Henry. 1997. "Trends in Long Term Employment in the United States, 1979-96," Working Paper No. 384, Industrial Relations Section Princeton University.

Gokhale, Jagadeesh, Erica L. Groshen and David Neumark. 1995. "Do Hostile Takeovers Reduce Extramarginal Wages? An Establishment-Level Analysis," Review of Economics and Statistics, pp. 470-485.

Gottschalk, Peter, and Robert Moffitt. 1998. "Changes in Job and Earnings Instability in the Panel Study of Income Dynamics and the Survey of Income and Program Participation," paper presented at Sage Foundation Conference on Changes in Job Stability and Job Security.

Hallock, Kevin F. 1998. "Layoffs, Top Executive Pay, and Firm Performance," American Economic Review, Vol.88, No. 4, September 1998, pp. 711-723.

Jaeger, David A., and Ann Huff Stevens. 1998. "Is Job Stability in the United States Falling? Reconciling Trends in the Current Population Survey and Panel Study of Income Dynamics," paper presented at Sage Foundation Conference on Changes in Job Stability and Job Security. 
Lazear, Edward P. 1979. “Why Is There Mandatory Retirement?” Journal of Political Economy, vol. 87, pp. 1261-1284.

Lazear, Edward P. 1995. Personnel Economics, Cambridge: MIT Press.

Lazear, Edward P. 1998. Personnel Economics for Managers, New York: Wiley.

Lieber, Ronald B. 1996. “How Safe Is Your Job?” Fortune, April 1, 1996, pp. 72-80.

McDevitt, Roland and Sylvester Schieber. 1996. From Baby Boom to Elder Boom: Providing Health Care for an Aging Population, Washington: Watson Wyatt Worldwide.

McGill, Dan, Kyle Brown, John Haley, and Sylvester Schieber. 1996. Fundamentals of Private Pensions, Philadelphia: University of Pennsylvania Press.

Moore, Thomas. 1996. The Disposable Work Force: Worker Displacement and Employment Instability in America. New York: Aldine de Gruyter.

Munk, Nina. 1999. “Finished at Forty,” Fortune, February 1, 1999, pp. 50-66.

New York Times. March 3-9, 1996. "The Downsizing of America," posted at http://www.nytimes.com/specials/downsize/glance.html

Neumark, David, and Daniel Polsky. 1998. "Changes in Job Stability and Job Security: Anecdotes and Evidence," Industrial Relations Research Association Papers and Proceedings, forthcoming.

Neumark, David, Daniel Polsky, and Daniel Hansen. 1997. "Has Job Stability Declined Yet? New Evidence for the 1990's.” NBER Working Paper No. 6330, December 1997.

Pennar, Karen. 1996. "Economic Anxiety,” Business Week, March 11, 1996.

Polsky, Daniel. 1996. "Changes in Consequences of Job Separations in the U.S. Economy," University of Pennsylvania unpublished manuscript.

Reich, Robert. 1997. Locked in the Cabinet, New York: Alfred Knopf.

Rose, Stephen. 1995. "Declining Job Security and the Professionalization of Opportunity," Washington: National Commission for Employment Policy Research Report No. 95-04.

Schieber, Sylvester and Laurene Graig. 1995. U.S. Retirement Policy: The Sleeping Giant Awakens, Washington: Watson Wyatt Worldwide. 
Sloan, Allan. 1996. “The Hit Men,” Newsweek, February 26, 1996, pp. 44-48.

U.S. Bureau of Labor Statistics. January 1997. "Employee Tenure in the Mid-1990s." Press release posted at http://stats.bls.gov/news.release/tenure.nws.htm

Worrell, Dan L., Wallace N. Davidson III, and Varinder M. Sharma. "Layoff Announcements and Stockholder Wealth," Academy of Management Journal, Vol. 34, No. 3, pp. 662-678. 